\title{
EFFECT OF SODIUM NITROPRUSSIDE AND TRIMETAPHAN ON NEUROMUSCULAR TRANSMISSION IN THE FROG
}

\author{
S.D. Gergis, M.D. Sokoll, ANd J.T. Rubbo
}

\section{INTRODUCTION}

THERE IS CURRENTLY a renewed interest in the production of controlled hypotension, not only to reduce bleeding during surgery in such situations as cerebral aneurysms and the excision of burns, but also for decreasing cardiac afterload in the treatment of myocardial infarction or during heart-lung bypass. The two agents most commonly used are sodium nitroprusside and trimetaphan. Because of the possibility of cyanide poisoning with nitroprusside, ${ }^{1}$ trimetaphan may be the preferred agent when prolonged control of blood pressure is needed. Recently there have been clinical reports of neuromuscular blockade following relatively large doses of trimetaphan. ${ }^{2.3}$ Similar clinical and laboratory observations were reported in the past. Randall, et al (1949), ${ }^{4}$ state that the drug had no curare-like blocking action on neuromuscular transmission. Although they reported that striated muscle action was not affected, the animals in their studies died of respiratory failure. Tewfik (1957) $)^{5}$ noted prolongation of succinylcholine paralysis when that drug was combined with trimetaphan. This action was attributed to pseudocholinesterase inhibition. However, Pearcy and Wittenstein $(1960)^{6}$ noted no increase in the effect of trimetaphan after the administration of a cholinesterase inhibitor. They concluded that trimetaphan is not destoryed by pseudocholinesterase. Payne $(1957)^{7}$ and Deacock and Davies $(1958)^{8}$ both suggest that trimetaphan has weak neuromuscular blocking properties. The absence of fasiculations suggested that the block was of a nondepolarizing nature. However, the block was accentuated by the administration of neostigmine.

This work was conducted to verify this neuromuscular blockading action of trimetaphan, to attempt to identify its site of action and to determine if nitroprusside has any effects on neuromuscular transmission and its site of action.

\section{Materials and Methods}

Crystalline sodium nitroprusside or trimetaphan camphosulfonate were dissolved in frog Ringer's solution and used for all experiments.

\section{A. Micro-electrode Studies}

All experiments were carried out in vitro on the isolated frog (Rana pipiens) sartorius muscle as described by Fatt and Katz (1955)," del Castillo and Katz

S.D. Gergis, M.D., M.D. Sokoll, M.D., and J.T. Rubbo, M.D., Department of Anaesthesia, University of Iowa Hospitals, Iowa City, Iowa 52242, U.S.A. 
(1955) ${ }^{10}$ and Sokoll, et al. (1972). ${ }^{11}$ Miniature end plate potentials (mepps) were recorded and frequency and amplitude were analyzed. Control observations were made for four minutes, then a solution containing the desired concentration of the drug was added to the bath for 10 minutes, after which mepp frequency and amplitude were recorded and changes were expressed as percentages of control.

\section{B. Acetylcholine Sensitivity}

The method of assaying the effect of iontophoretic micro-application of acetylcholine was similar to that employed by del Castillo and Katz (1955) ${ }^{10}$ and Sokoll, et al. (1972). ${ }^{11}$ Acetylcholine was delivered by application of an electric pulse of $1 \mathrm{~Hz}$ for $10 \mathrm{msec}$. After obtaining a control sensitivity the desired drug concentration was added to the bath for 10 minutes and sensitivity was again recorded. Changes were expressed as percentage of control.

\section{Action Potential Generation Studies}

For the recording of action potentials in the frog sartorius muscle, two microelectrodes were inserted into the same muscle cell with a 50-100 $\mu$ interelectrode distance. One of the electrodes was used to stimulate the fiber by a depolarizing current of $5 \mathrm{msec}$ duration and the other for recording the resulting action potential. The action potentials were analyzed for threshold, spike amplitude and rate of rise of the spike. Changes after drug application were expressed as percentages of control.

\section{Input Resistance}

The method for recording input resistance was similar to that used by Sokoll and Thesleff (1968). ${ }^{12}$

\section{E. Twitch Tension}

The sartorius muscle was stimulated through its nerve by a current of $0.2 \mathrm{~Hz}$, $0.1 \mathrm{msec}$ and $3 \mathrm{~V}$. After the muscle twitch had stabilized, the desired concentration of the drug was added to the bath and the resulting twitches were compared to control. Results were expressed as percentages of control.

\section{F. Acetylcholine-Induced Contracture}

The effect of trimetaphan on acetylcholine-induced contracture was studied on frog rectus abdominis muscle. Frog rectus abdominis muscle was dissected bilaterally and each muscle was suspended in a vertical bath of $10 \mathrm{ml}$ capacity with one end attached to a fixed rod and the other to a force displacement transducer. The preparation was bathed in oxygenated frog Ringer's solution. Different volumes of a concentrated solution of acetylcholine were added to the bath to achieve final concentrations of $2.5 \times 10^{-7}, 5 \times 10^{-7}$ and $10^{-6} \mathrm{~g} / \mathrm{ml}$ and the resulting contracture was measured. The volume of acetylcholine added $\left(0.025\right.$ to $0.1 \mu \mathrm{l}$ of $10^{-4}$ solution) was insignificant to alter the final concentration of the agent. These acetylcholine concentrations were chosen because the $10^{-6} \mathrm{~g} / \mathrm{ml}$ acetylcholine solution produced a maximum contracture, while the other lesser concentrations produced about 25 per cent and 50 per cent of this maximum. 
After the control measurements were obtained, the bath was emptied and refilled with frog Ringer's solution containing a specific amount of trimetaphan. The same volumes of stock acetylcholine solution were added to obtain the previous concentrations and the resulting contractures were measured and compared to control values. The values were normalized by considering the maximum contracture as 100 per cent and all other contractures were expressed as a percentage of this value for each muscle.

The effects of sodium nitroprusside on MEPP amplitude and frequency, muscle twitch tension and rectus abdominis contracture were studied.

\section{Statistics}

Statistical analysis using Student's t-test for paired experiments were performed on all results. ${ }^{13}$ Comparison was made between the control and drug-treated results at the various concentrations studied. Significance was considered at a $\mathrm{p} \leqq 0.05$.

\section{Results}

MEPP frequency was increased to 160 per cent of control in the presence of trimetaphan $10^{-5} \mathrm{~g} / \mathrm{ml}$, decreasing to 117 per cent at $5 \times 10^{-5} \mathrm{~g} / \mathrm{ml}$ (Figure 1). MEPP amplitude was 97 per cent of control at $10^{-5} \mathrm{~g} / \mathrm{ml}$ and decreased to 36 per cent of control at the higher concentration of $5 \times 10^{-5} \mathrm{~g} / \mathrm{ml}$ (Figure 2). There was no change in resting membrane potential with drug application.

The sensitivity of the endplate to iontophoretically applied acetylcholine followed the trend of mepp amplitude and was 81 per cent of control at $10^{-5} \mathrm{~g} / \mathrm{ml}$ and 37 per cent of control at $5 \times 10^{-5} \mathrm{~g} / \mathrm{ml}$ (Figure 3 ). The action potential generation studies revealed that at a concentration of trimetaphan $10^{-5} \mathrm{~g} / \mathrm{ml}$, the threshold and the amplitude of the generated spike were increased to 112 per cent of control and there was a 121 per cent faster rate of rise than the control. However, at the higher concentration of $5 \times 10^{-5} \mathrm{~g} / \mathrm{ml}$ there was a drop to about 95 per cent of control of all three parameters (Figure 4). These changes were not statistically significant.

There was no significant change in muscle membrane input resistance studies in the concentration range studied.

There was a dose-related, statistically significant depression of sartorius twitch response. When exposed to trimetaphan $2.5 \times 10^{-5} \mathrm{~g} / \mathrm{ml}$ the twitch was 60 per cent of control and dropped to 30 per cent of control at $7.5 \times 10^{-5} \mathrm{~g} / \mathrm{ml}$ concentration (Figure 5).

On the rectus abdominis preparations, trimetaphan showed statistically significant depression of the acetylcholine-induced contracture; trimetaphan $7.5 \times 10^{-5}$ $\mathrm{g} / \mathrm{ml}$ reduced the rectus contracture approximately 50 per cent when exposed to different concentrations of acetylcholine $\left(2.5 \times 10^{-7}, 5 \times 10^{-7}\right.$ and $\left.10^{-6} \mathrm{~g} / \mathrm{ml}\right)$ (Figure 6).

Sodium nitroprusside produced no inhibition of acetylcholine-induced contractures over a drug concentration range of $10^{-8}$ to $10^{-3} \mathrm{~g} / \mathrm{ml}$. Over the same concentration range no effects were seen on twitch tension, mepp amplitude or frequency, 


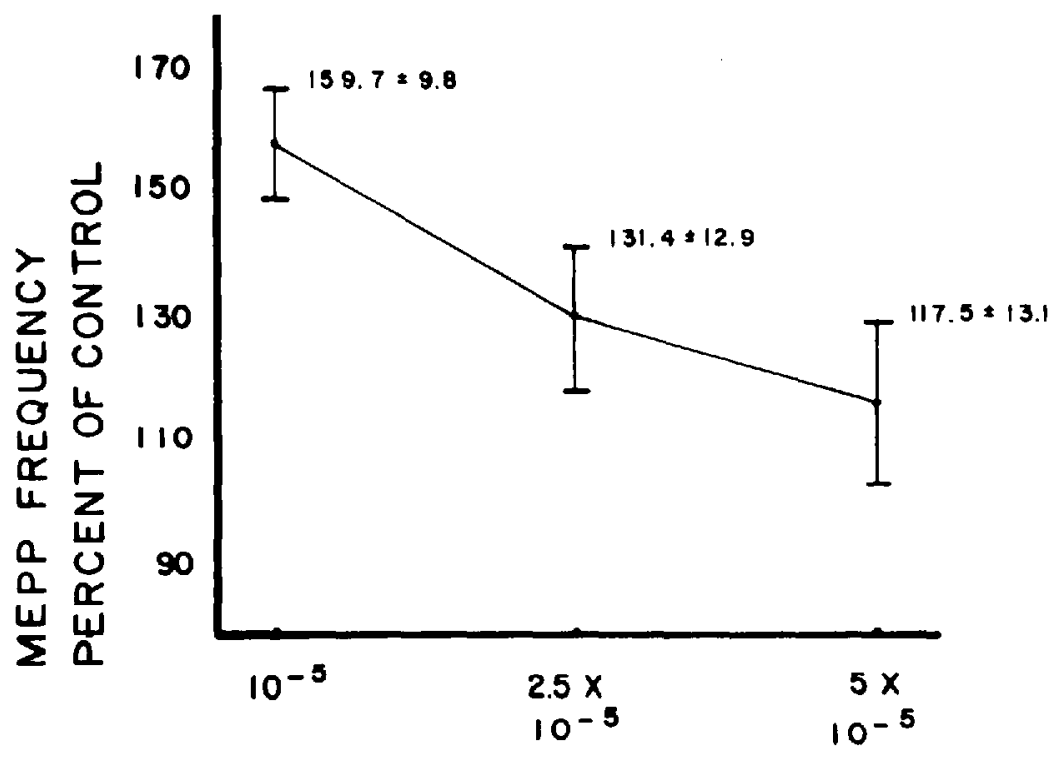

TRIMETAPHAN $g / \mathrm{ml}$

Figure 1. Effect of trimetaphan on mepp frequency, $n=10$, value $=$ mean $\pm S E$.

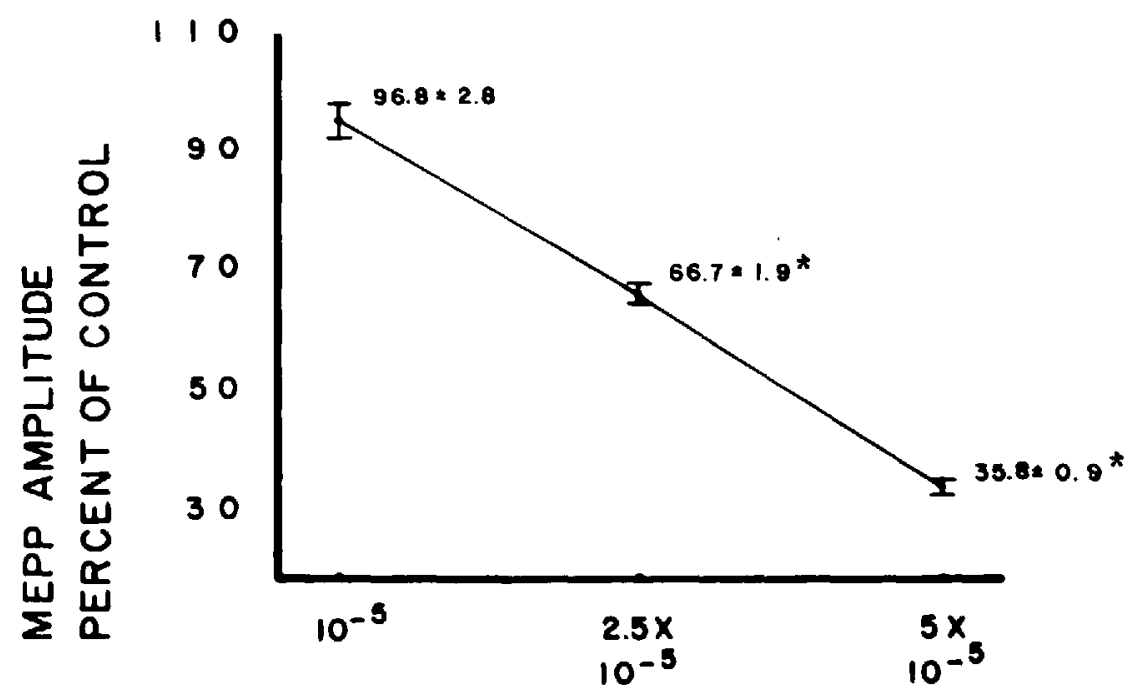

\section{TRIMETAPHAN $0 / \mathbf{m l}$}

Figure 2. Effect of trimetaphan on mepp amplitude; $n=10$, value $=$ mean \pm SE. ${ }^{\circ} \mathrm{P}<0.001$.

or resting membrane potential. In light of these negative studies, further investigation for neuromuscular blockade was deemed fruitless.

The drug concentrations used were chosen to correlate with clinically administered drug dosages, if we assume the drug concentration at the receptor to be the 


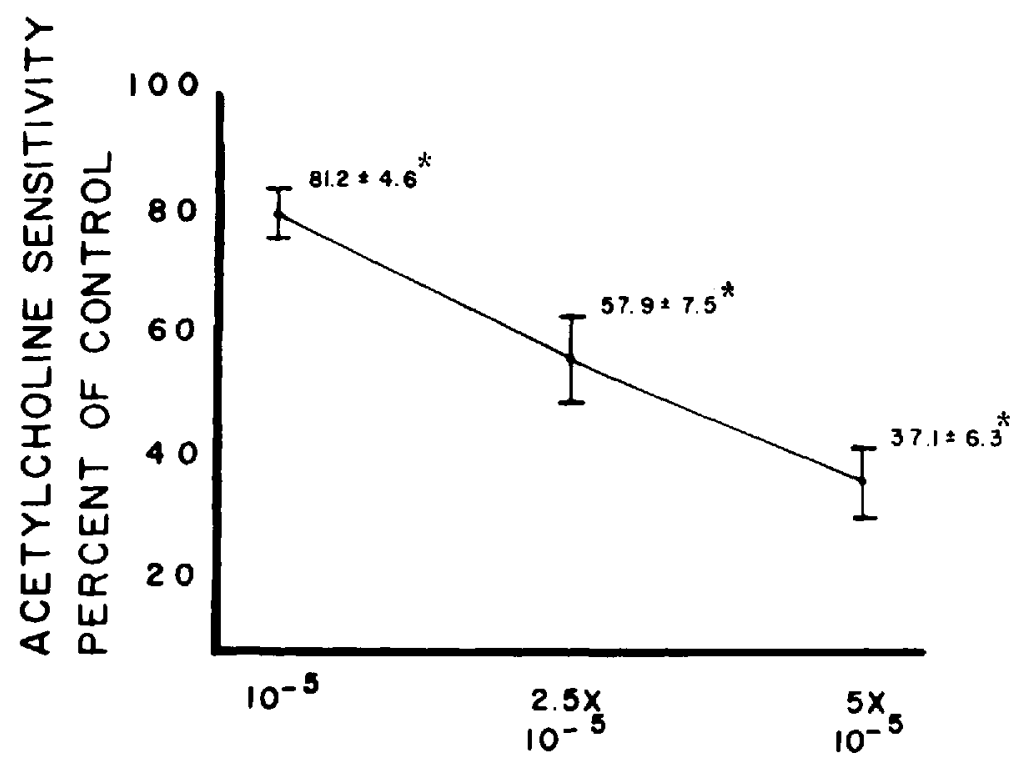

TRIMETAPHAN $g / m l$

FIGURE 3. Effect of trimetaphan on sensitivity of endplate to iontophoretically applied acetylcholine; $\mathrm{n}=8$, value $=$ mean $\pm \mathrm{SE}$. ${ }^{\circ} \mathrm{P}<0.001$.
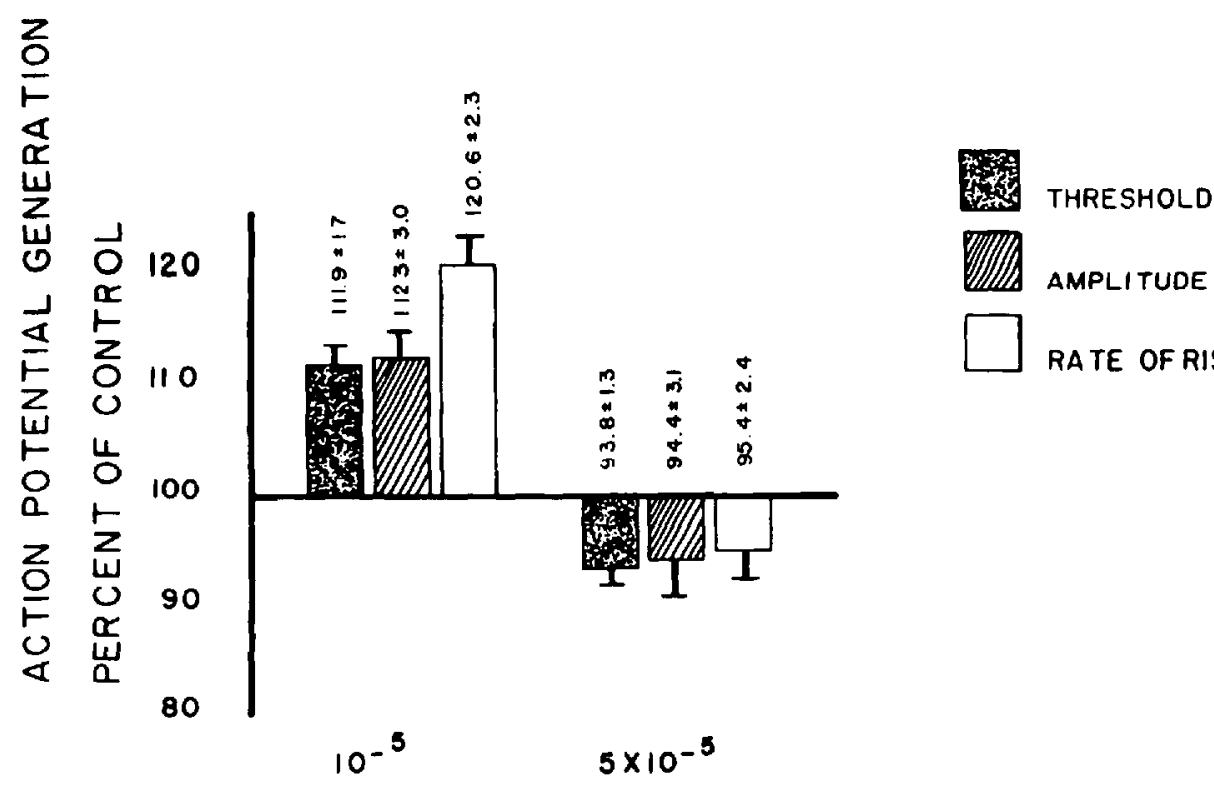

THRESHOLD

IIIII AMPLITUDE

$\square$ RATE OF RISE

\section{TRIMETAPHAN $q / \mathrm{ml}$}

FIgURE 4. Effect of trimetaphan on different parameters of action potential generation; $n=8$, value $=$ mean $\pm \mathrm{SE}$. 


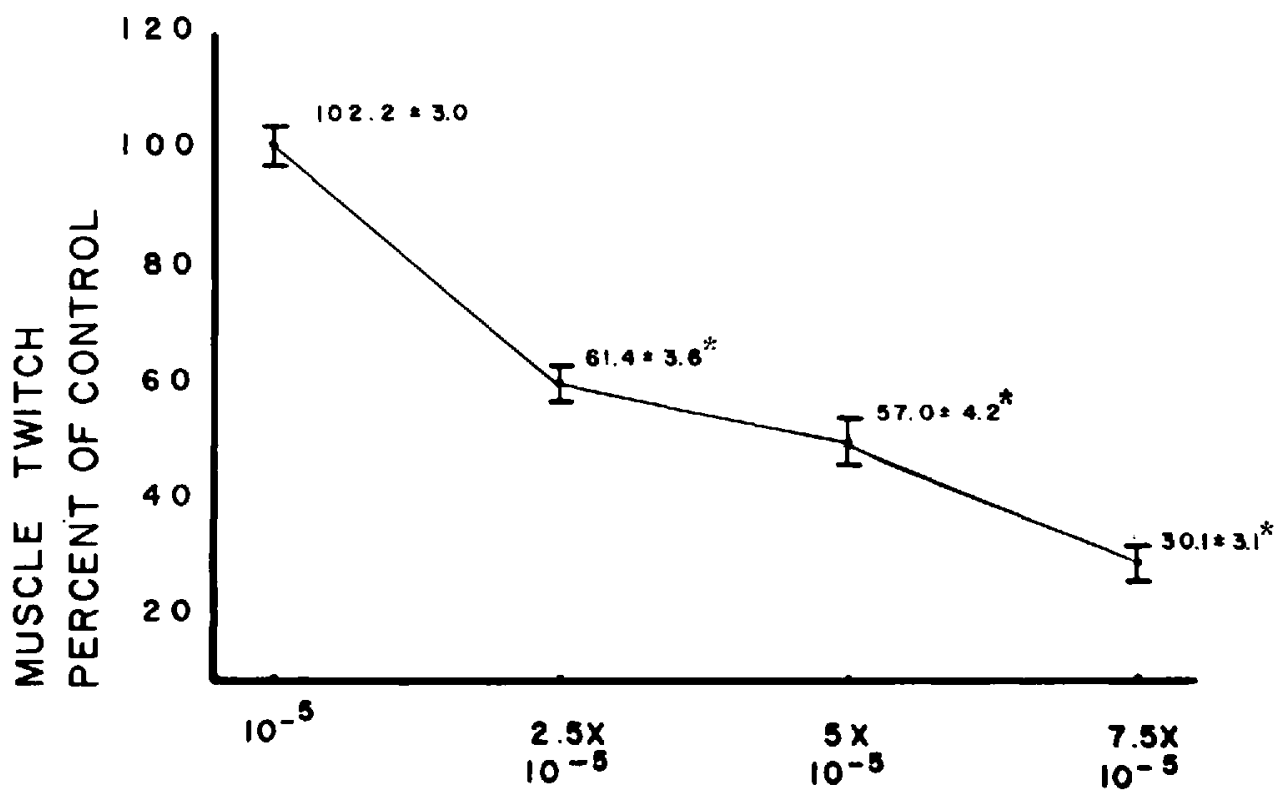

TRIMETAPHAN $g / m I$

Ficune 5. Effect of trimetaphan on the twitch height of indirectly stimulated frog sartorius; $\mathrm{n}=8$, value $=$ mean $\pm \mathrm{SE} .{ }^{\circ} \mathrm{P}<0.001$.

- CONTROL

$X$ TRIMETAPHAN

$7.5 \times 10^{-8}$

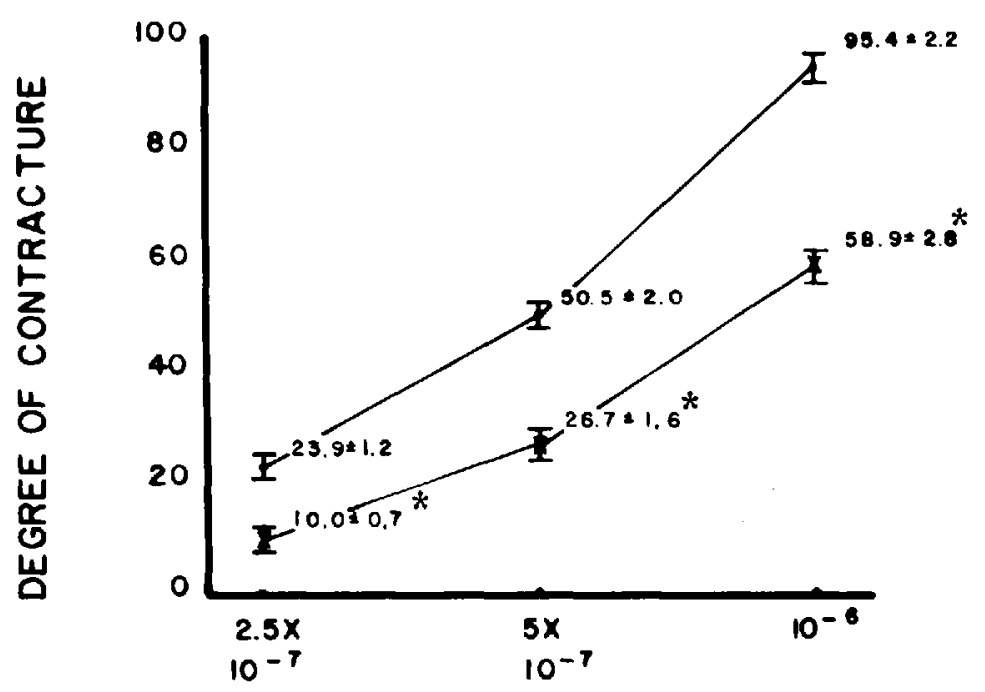

ACETYLCHOLINE $0 / \mathrm{ml}$

Figure 6. Effect of trimetaphan $7.5 \times 10^{-5} \mathrm{~g} / \mathrm{ml}$ on acetylcholine-induced frog rectus contracture; $n=20$, value $=$ mean $\pm S E .{ }^{\circ} \mathrm{P}<0.001$. 
result of dilution of the administered dose in the extracellular fluid volume of a $70-\mathrm{kg}$ man, i.e. 14 litres. Hence, the dose range described for trimetaphan would be about 350 to $1000 \mathrm{mg}$. Sodium nitroprusside $10^{-8} \mathrm{~g} / \mathrm{ml}$ would equate to an administered dose of approximately $0.15 \mathrm{mg}$ total dose. The highest accepted dose is 3 to $3.5 \mathrm{mg} / \mathrm{kg}^{1}$ or about $2 \times 10^{-5} \mathrm{~g} / \mathrm{ml}$ in this study.

\section{Discussion}

Isolated clinical reports dating back to 1949 suggested that trimetaphan might have neuromuscular blocking properties. This block was attributed mainly to fall in blood pressure and diminished muscle perfusion or to an anticholinesterase property. The similarity of the blockade produced by trimetaphan and curare was noticed by Deacock and Davies (1958) and Pearcy and Wittenstein (1960).

The results presented here support the concept of a nondeplorazing neuromuscular blockade produced by trimetaphan. Increases in mepp frequency such as those reported here have been interpreted by $\mathrm{Katz}^{14}$ to indicate nerve terminal stimulation. The predominant effect of the drug, however, appears to be that of postsynaptic receptor blockade. Evidence for this is the concomitant decrease in mepp amplitude and the diminished sensitivity of the endplate to iontophoretically applied acetylcholine. No change in resting membrane potential was noted. This is characteristic of nondepolarizing neuromuscular blocking drugs. Additional support for the concept of cholinergic receptor blockade is provided by the decrease in twitch tension without the occurrence of contracture, as well as the decreased acetylcholine-induced contracture of the frog rectus abdominis muscle.

It was suggested by Tewfik $^{5}$ that trimetaphan inhibits pseudocholinesterase. Drugs which inhibit true cholinesterase, which also usually inhibit pseudocholinesterase, should produce an increased amplitude of mepps. This was not observed.

It is apparent from these results that neuromuscular blockade can be produced by trimetaphan and is a dose-related phenomenon. As the drug is excreted partly by the kidney, it is conceivable that continuous administration over a long period of time will result in accumulation and hence in a higher concentration. The receptor depression also suggests that the drug should have at least an additive effect when combined with d-tubocurarine.

This report shows that, at least on the parameters studied, sodium nitroprusside does not affect neuromuscular transmission in the frog.

In the operating room the use of trimetaphan to induce hypotension may result in an exaggerated response to the commonly used muscle relaxants. From this point of view, sodium nitroprusside may be preferable to trimetaphan for the production of induced hypotension during operation.

\section{SUMMARY}

In summary, it appears from this and other studies that trimetaphan has the potential for producing neuromuscular blockade when used in large doses or when combined with other muscle relaxants. The mode of action appears to be principally that of non-depolarizing neuromuscular blockade. Sodium nitroprusside, on the 
other hand, even in doses beyond these accepted clinically, does not affect neuromuscular transmission and unless otherwise contraindicated is safe to use with muscle relaxants.

\section{RÉSUMÉ}

Les effets du Nitroprussiate de sodium et ceux du Trimetaphan sur la transmission neuromusculaire ont été étudiés chez la grenouille. Le Nitroprussiate ne modifie pas la transmission neuromusculaire alors que le Trimetaphan a des effets bloqueurs surtout au niveau du récepteur post-synaptique.

\section{REFERENCES}

1. Tinken, J.H. \& MichenfeLden, J.D. Sodium nitroprusside - pharmacology, toxicology and therapeutics. Anesthesiology 45: 340-354 (1976).

2. WILsON, S.L., MilLEF, R.N., Wricht, C., \& HASSE, D. Prolonged neuromuscular blockade associated with trimethaphan; A case report. Anesthesia and Analgesia 55: 353-356 (1976).

3. Gutiernez, J. The neuromuscular blocking effects of trimethaphan (Arfonad). Abs. Sci. Papers - A.S.A., p. 567 (1976).

4. Randale, L.O., Peterson, W.G., \& Lemman, G. The ganglionic blocking action of thiophanium derivatives. J. Pharmacol. Exper. Therap. 97: 48-57 (1949).

5. TWEFIK, G. Trimethaphan, its effect on the pseudo-cholinesterase level of man. Anesthesia 12: 326-329 (1957).

6. Pearcy, W.E. \& Wittenstein, E.S. The interactions of trimethaphan (Arfonad), suxamethonium and cholinesterase inhibitors in the rat. Br. J. Anaes. 32: 156-158 (1960).

7. PAYNE, J.P. The influence of mecamylamineon the action of certain other ganglion blocking agents. Brit. J. Anaes. 29: 358-362 (1957).

8. Deacock, A.R. \& Davies, T.D.W. The influence of certain ganglion blocking agents on neuromuscular transmission. Brit. J. Anaes. 30: 217-225 (1958).

9. FATT, P. \& KATZ, B. An analysis of endplate potential recorded with an intracellular electrode. J. Physiol. 115: 320-370 (1951).

10. del Castillo, J. \& Katz, B. On the localization of acetylcholine receptors. J. Physiol. 28: $157-181(1955)$.

11. Sokoll, M.D., Dretchen, K.L., Gergis, S.D., et al. d-Tubocurarine effects on nerve terminal and neuromuscular conduction. Anesthesiology 36: 592-597 (1972).

12. SokolL, M.D. \& TheslefF, S. Effects of $\mathrm{pH}$ and uranyl ions on action potential and acetylcholine sensitivity of skeletal muscle. European J. Pharmacol. 4: 71-76 (1968).

13. Steel, R.G.D. \& Torrie, J.H. Principles and procedures of statistics. New York, McGrawHill, pp. 67-109 (1960).

14. KATZ, B. The transmission of impulses from nerve to muscle and the subcellular unit of synaptic action. Proc. Roy. Soc. Lond. (Biol.) 155 Series B, pp. 455-477 (1962). 